\title{
Antibacterial activity and composition of decellularized goat lung extracellular matrix for its tissue engineering applications
}

\author{
Sweta K. Gupta ${ }^{1}$, Amit K. Dinda ${ }^{2}$ and Narayan C. Mishra ${ }^{1 *}$ \\ ${ }^{1}$ Department of Chemical Engineering, University of Rhode Island, USA \\ ${ }^{2}$ Department of Pathology, All India Institute of Medical Sciences, New Delhi, India
}

\begin{abstract}
In this study, scaffold was fabricated from goat-lung of cadaver goat by decellularization method for its potential application in tissue engineering. The cellular components of goat-lung were removed by employing trypsin-SDS based method of decellularization. DNA quantification and DAPI staining verified the effective removal of native cells from the goat-lung. Verhoeff-Van Gieson (VVG) staining, H\&E staining and Periodic-Acid Schiff (PAS) staining histologically assessed the composition of native and decellularized goat-lung matrix-demonstrating the presence of collagen, elastin and glycoproteins in the decellularized goat-lung matrix. Antibacterial activity of decellularized goat-lung matrix was evaluated against gram-negative (Escherichiacoli) and gram-positive (Staphylococcusaureus) bacteria, which shows the presence of naturally occurring bioactive peptides-exhibiting the antibacterial activity against $E$. coli for up to $9 \mathrm{~h}$ and against $S$. aureus for up to $5 \mathrm{~h}$. The decellularized goat-lung matrix, as demonstrated by MTT assay, was found to be biocompatibile to L929 mouse fibroblasts, HepG2, human skin derived mesenchymal stem cells (hS-MSCs), osteoblasts and BMMSCs. All the above results confer the applicability of the decellularized goat-lung matrix as a potential scaffold for tissue engineering applications.
\end{abstract}

\section{Introduction}

Tissues are made up of cells, which are surrounded by extracellular matrix (ECM) consisting of various structural and functional proteins, e.g., collagen, fibronectin, laminin, proteoglycans and glycoproteins. In a tissue, the ECM of each cell is connected to the ECM of other cellsbuilding three-dimensional (3D) cell-ECM architecture. If all the cells residing in a tissue are removed, a 3D architecture of ECM will be left behind, which could act as a scaffold for supporting new cells for tissue regeneration [1-5]. Various scientists have been trying to use the ECM (allogeneic or xenogeneic) network as scaffold for regenerating neotissues. Many organs, e.g. urinary bladder [6], small intestinal [7-11], heart valves [12-15], skin [16,17], liver [18], anterior crucial ligament bone [19], kidney [20], pericardium [21], blood vessels [22], nerves [23], skeletal muscle [24], tendon [25] and vocal cord [26,27] from bovine and porcine tissues, have been used for fabricating the ECMbased scaffold. But, the use of goat-lung has not been focused for tissue engineering applications. The development of scaffolds, from bovine and porcine tissues, possesses a risk of disease transmission from bovine and porcine tissues to humans [28-33], and their use in clinical applications might involve high risk of disease in recipient humans, e.g., Creutzfeldt-Jakob disease. On the other hand, goat tissue could be a better choice as they are least susceptible to viruses [34]. Besides, the prions (viruses) of goat scrapie have not yet been reported to cause any disease in humans [30,35-37] . Therefore, goat tissue could be a safer option, as there will be no/minimal risk to human health if they are used for fabricating scaffold for tissue engineering. Lung is highly porous and therefore the ECM from goat-lung, after cell removal, is supposed to provide a $3 \mathrm{D}$ highly porous architecture with a complex mixture of both structural and functional proteins [34,38]. Collagen is an important component in lung ECM for providing strength to the tissue and elastin fibers helps in natural recoiling of lung [39]. The assessment of ECM proteins (collagen, elastin and glycoproteins) present in the decellularized lung matrix is important as these proteins influence the growth and proliferation of cells in the tissue. Therefore, one of our aims is to investigate about the composition of decellularized goat-lung matrix for its applicability as scaffold for tissue engineering applications.

The components present in the ECM are subject to degradation during constructive tissue remodeling. The matrix, during degradation/ proteolysis, releases various kinds of bioactive peptides/matricryptic molecules, which play significant role in cell recruitment and constructive restoration of the tissue [40-42]. Some of these bioactive peptides released during degradation have been reported to possess antibacterial properties that are essential for providing instantaneous protection in prevention of an implant-infection in the duration when the inflammatory cellular response and humoral immune response of the host become activated [40,43-56]. We hypothesize that such antibacterial activity exists within the goat-lung matrix. The antibacterial property of the goat-lung matrix has not been reported and therefore, we aim to investigate this important aspect, as this

Correspondence to: Dr. Narayan C. Mishra, Department of Polymer and Process Engineering, Indian Institute of Technology Roorkee, India; E-mail: mishrawise@gmail.com

Key words: antibacterial activity, decellularized scaffold, extracellular matrix, goat-lung, tissue engineering

Received: January 07, 2017; Accepted: January 25, 2017; Published: January 28 2017 
property, if present, will make the decellularized goat-lung matrix a prime scaffold for tissue engineering applications. Our objective is to explore the cadaver goat-lung for tissue engineering applications, and in this work we aim to assess the ECM components and antibacterial property of the decellularized goat-lung matrix.

\section{Materials and methods}

\section{Materials}

Dulbecco's Phosphate Buffered Saline (PBS-/-, without $\mathrm{Ca}^{2+}$ and $\mathrm{Mg}^{2+}$ ), Mueller Hinton (MH) broth, antibiotic antimycotic solution 100X liquid (endotoxin tested), collagenase enzyme, 3-(4,5-dimethylthiazol-2-yl-2, 5-diphenyltetrazolium bromide) (MTT), ethanol, RNase, DNase, dimethyl sulphoxide (DMSO) and agar powder (bacteriological grade) were purchased from Himedia Laboratories Pvt. Limited, Mumbai, India. $0.25 \%$ trypsin containing $0.02 \%$ ethylene-diamine-tetra-acetic acid ( $0.25 \%$ trypsin-EDTA) was obtained from Himedia, India. Ethylene diamine tetra acetic acid (dehydrate) dipotassium salt (EDTA) was obtained from Fischer Scientific. Tetracycline was obtained from Sigma, St. Louis, MO, U.S.A. Fetal bovine serum (FBS) was received from Hyclone, USA. T-75 flasks and Petri dishes $(35 \mathrm{~mm})$, for cell culture, were obtained from Nunc, India. Double distilled water was prepared in our laboratory and the same was used during experiment.

\section{Decellularization of goat-lung tissue}

In order to decellularize the cadaver goat-lung tissue, it was first sectioned into $1 \mathrm{~cm}^{2}$ dimensions, and then treated with $0.25 \%$ trypsinEDTA in 1X PBS supplemented with $1 \%$ antibiotic-antimycotic solution to detach the cells from their ECM. Subsequent treatments were carried out by agitating the tissue in $0.1 \%$ SDS in $1 \mathrm{X} \mathrm{PBS}$ at $37^{\circ} \mathrm{C}$ for $6-8 \mathrm{~h}$, followed by treating in a solution containing RNase $(20 \mu \mathrm{g} / \mathrm{ml})$ and DNase $(0.2 \mathrm{mg} / \mathrm{ml})$ for $24 \mathrm{~h}$. The decellularized goat-lung sections were then disinfected, by gently shaking in an aqueous solution of $0.1 \%$ (v/v) hydrogen peroxide (oxidizing agent) and $4 \%(\mathrm{v} / \mathrm{v}$ ) ethanol, for $2 \mathrm{~h}$. The tissue sections were then extensively rinsed with 1X PBS to remove any residual oxidizing agent present in the tissue. The goat-lung matrix, after decellularization, was stored in $1 \mathrm{X}$ PBS at $4^{\circ} \mathrm{C}$ prior to further processing and seeding.

\section{Verification of decellularization}

The complete removal of cells, after decellularization, was verified quantitatively by estimating the DNA content of the native tissue and the decellularized tissue. The total genomic DNA of native and decellularized goat-lung tissue was isolated with the help of phenolchloroform-isoamyl alcohol method. In brief, the weighed tissue samples $(n=3)$ were at first minced with the scissors and degraded with $0.1 \%$ collagenase at $37^{\circ} \mathrm{C}$. Subsequently samples were centrifuged at $14,000 \mathrm{rpm}$ and the supernatant was collected. The phenol-chloroformisoamyl alcohol (25:24:1) were then added and centrifuged again. The supernatant was siphoned and precipitated by $100 \%$ ethanol at $-85^{\circ} \mathrm{C}$ for 45 minutes followed by centrifugation at $14,000 \mathrm{rpm}$ for 10 minutes. The pellets were rehydrated in 1X Tris-EDTA buffer and quantified at $260 \mathrm{~nm}$, using spectrophotometer (Eppendorf Biophotometer, Hamburg, Germany). The removal of cells from the goat-lung tissue was also verified using DAPI (4' 6-diamidino-2-phenylindole) fluorescent staining. After the decellularization process, the goat-lung tissue section was stained with DAPI to observe any stained nucleus in the tissue. DAPI stained decellularized tissues were then incubated in the dark for $30 \mathrm{~min}$ at room temperature, and visualized by an inverted microscope (Axiovert 25, Carl Zeiss, Germany). The images were captured with an attached camera linked to computer.

\section{Histological assessment of decellularized goat-lung matrix}

Tissues were fixed in neutral buffered formalin and then embedded in paraffin. The paraffin embedded native and decellularized goat-lung tissues were sectioned ( $5 \mu \mathrm{m}$ in thickness). The effectiveness of trypsinSDS based decellularization to remove cells from the native goat-lung tissue and the preservation of ECM components (collagen, elastin, glycoproteins) was evaluated by different staining methods. The tissue sections were stained using Hematoxylin and Eosin (H\&E) staining, Verhoeff-Van Gieson (VVG) staining for assessment of collagen and elastin, and Periodic-Acid Schiff (PAS) staining for evaluation of glycoproteins present in the native and decellularized goat-lung tissue. The quantitative assessments of the stained decellularized sections were done by using Image J program (ImageJ 1.40g, Wayne Rasband, National Institute of Health, USA) as previously reported [57,58].

\section{In vitro biodegradation of decellularized goat-lung matrix}

The decellularized goat-lung tissue was weighed and placed in $10 \mathrm{~mL}$ of 1X PBS ( $\mathrm{pH} 7.4$ ) having collagenase from Clostridiumhistolyticum $(125 \mathrm{U} / \mathrm{mg})$ and incubated in the shaking incubator at $37^{\circ} \mathrm{C}$ for $60 \mathrm{~h}$. At different time intervals, the decellularized tissues were removed from the shaker, lyophilized and weighed. The in vitro biodegradation of the goat-lung tissue $(n=3)$ were calculated by using the following equation:

Weight loss $(\%)=100 \times\left[\mathrm{W}_{0}-\mathrm{W}_{\mathrm{t}} / \mathrm{W}_{0}\right]$

where, $\mathrm{W}_{0}$ denotes the initial weight of the decellularized goat-lung tissue, and $\mathrm{W}_{\mathrm{t}}$ denotes the weight of the degraded scaffold at different time intervals.

\section{Assessment of antibacterial activity of decellularized goat- lung matrix}

The antibacterial activity of decellularized goat-lung matrix was assessed against gram-negative Escherichia coli (E. coli, strain NCIM 2931) and gram-positive Staphylococccus aureus (S. aureus, strain MTCC 3160). MH broth and MH agar were prepared according to the manufacturer's instructions and incubated overnight at $37^{\circ} \mathrm{C}$ to confirm sterility. $\mathrm{MH}$ agar plates were streaked with $E$. coli and $S$. aureus, and isolated colonies (2-3 lag phase growth) were picked and transferred into vials containing $10 \mathrm{~mL}$ of $\mathrm{MH}$ broth, and incubated at $37^{\circ} \mathrm{C}$ overnight in shaker. When the culture reached an optical density of 0.1 at $570 \mathrm{~nm}$, the cultures were harvested from $\mathrm{MH}$ broth, diluted to $105 \mathrm{CFU} / \mathrm{mL}$, and $100 \mu \mathrm{L}$ of bacterial suspension were added to each well of a 96-well culture plate. On the other hand, $100 \mathrm{~g}$ of goatlung matrix ( $90 \%$ moist) was suspended in $10 \mathrm{~mL} 1 \mathrm{X}$ PBS containing collagenase $(2 \mathrm{mg} / \mathrm{mL})$. The matrix was incubated in shaker at $37^{\circ} \mathrm{C}$ for complete degradation until no visible pieces of the tissue remains in the tube. $25 \mu \mathrm{L}$ of degraded goat-lung matrix was added to both the bacterial suspension. Tetracycline (broad-spectrum antibiotic) was used as an antibiotic control for both $E$. coli and $S$. aureus bacterial cultures. The stock solution of tetracycline $(10 \mathrm{mg} / \mathrm{mL})$ was prepared in 50\% methanol. MH broth (without matrix) was taken as negative control and E. coli and S. aureus bacterial suspension were taken as positive controls. The absorbance was measured at different predetermined time intervals at $570 \mathrm{~nm}$. In an effort to eliminate errors in the procedure, all assays were performed in triplicates.

\section{Biocompatibility and cell viability study by MTT assay}

MTT assay is a colorimetric test based on the conversion of MTT 
tetrazolium salts into purple colored formazan products. Only viable cells with active metabolism are able to convert MTT into tetrazolium salt, therefore, the intensity of color formation is directly proportion to the number of viable cells. Various different types of cells: L929 mouse fibroblasts, HepG2, skin derived mesenchymal stem cells (hS-MSCs), osteoblasts and bone derived mesenchymal stem cells (BMMSCs) were maintained in DMEM with $10 \%$ FBS and $1 \%$ PenStrep solution in a $5 \% \mathrm{CO}_{2}$ incubator at $37^{\circ} \mathrm{C}$ (Binder, Germany). Xenogeneic goat-lung decellularized matrix sectioned into approximately $1 \mathrm{~mm}^{3}$ sizes, and 4-5 sections were plated in the 96 -well plate to cover the entire surface with scaffolds, in triplicates. The scaffolds were then UV sterilized in the laminar airflow chamber for $30 \mathrm{~min}$, and the cells were seeded. All the cells were seeded at the density of $1 \times 10^{3}$ cells/well directly over the scaffold, in triplicate, and incubated for $5 \mathrm{~min}$ to maximize the adherence of cells only to scaffold and provide minimum chance to dribble into the culture plate. DMEM was then added into the wells containing decellularized scaffold with cells to make up the volume $200 \mu \mathrm{l}$. After respective time period of $48 \mathrm{~h}, 10 \mu \mathrm{l}$ of MTT solution $(5 \mathrm{mg} /$ $\mathrm{ml}$ ) and $90 \mu \mathrm{l}$ of DMEM were added in each well, and incubated for $4 \mathrm{~h}$. After incubation, purple colored formazan crystals were dissolved with $100 \mu \mathrm{l}$ DMSO and absorbance was taken at $490 \mathrm{~nm}$ with the subtraction for plate absorbance at $650 \mathrm{~nm}$. The recorded absorbance value (i.e. O.D.) is considered as a measure of cell viability.

\section{Statistical analysis}

Antibacterial activity, biocompatibility and cell viability study of decellularized goat-lung matrix were obtained in triplicate samples. Data were expressed as the mean \pm standard deviation. Using MINITAB statistical software (MINITAB release 13.32), statistical analysis (ANOVA test) was performed with $\mathrm{p}<0.05$ considered as being statistically significant.

\section{Results and discussion}

\section{Decellularization of goat-lung matrix and its verification}

Cellular components, if present in the matrix, could elicit an immune response to host [59], therefore, an effective removal of cells from the matrix is important. To verify the effectiveness of the decellularization method and complete removal of cells from the goat-lung matrix, DNA quantification and DAPI staining had been performed (Figure 1). It was observed (Figure 1A) that the DNA content of the decellularized tissue was significantly less $(34.2 \pm 6.5$
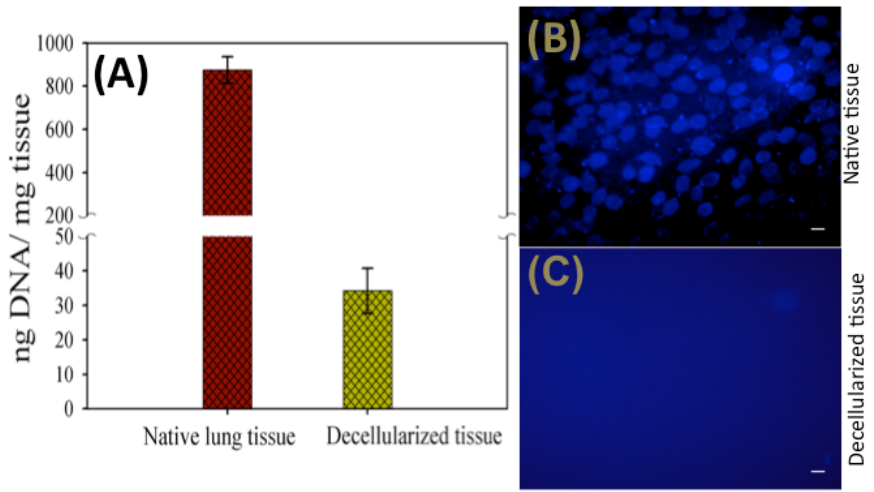

DAPI staining

Figure 1. (A) DNA content of native and decellularized tissue indicating significant decrease in the DNA after decellularization, and (B) DAPI staining showing positive nuclear staining in the native tissue indicating the presence of cells, and $(\mathrm{C})$ negative nuclear staining in the decellularized tissue indicating absence of cells. Sacle bars: $50 \mu \mathrm{m}$. ng DNA/mg of dry weight decellularized tissue) as compared to the native tissues $(875.3 \pm 61.42 \mathrm{ng} \mathrm{DNA} / \mathrm{mg}$ of dry weight native tissue)indicating effective removal of cells from the native tissue (Table 1). It has been reported that if the DNA content of a tissue is less than 50ng DNA/mg dry weight of ECM, then the adverse host immune response, after implantation [60], can be avoided. The residual DNA content of $34.2 \mathrm{ng}$ per $\mathrm{mg}$ of decellularized tissue indicates that it is below the threshold amount of 50ng DNA/mg tissue, and therefore, it should not induce any immunogenic response. The negative cell nuclei staining by DAPI stain (Figure 1B and Figure 1C) also demonstrated the efficient removal of cells from the goat-lung and supported the result of DNA quantification study. The native goat-lung tissue (control) containing cells showed positive nuclear staining by DAPI stain. These methods have been used repeatedly by several researchers for assessment of cell removal from the decellularized tissues [61-63]. DNA quantification and DAPI staining thus verified the efficient removal of cells from the goat-lung tissue demonstrating the applicability of decellularized goatlung matrix as a scaffold.

\section{Histological assessment of decellularized goat-lung matrix}

VVG staining of the native goat lung matrix indicated the presence of collagen fibers (red), elastin fibers (black) and nuclei (blue) (Figure $2 \mathrm{~A}$ ), however in the decellularized matrix, it showed the presence of collagen (red) and elastin fibers (black) only, with the absence of cell

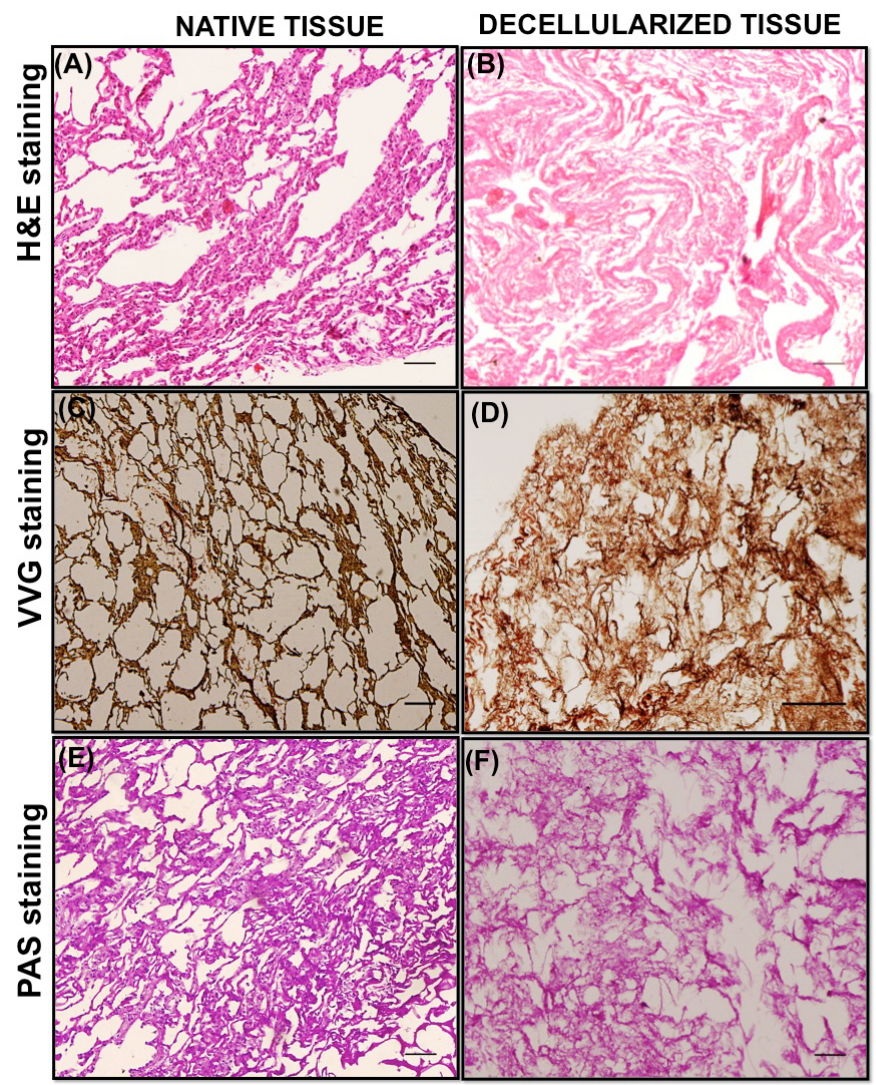

Figure 2. Representative staining images of native and decellularized goat-lung tissue $A-B$ panels: Hematoxylin and Eosin staining of native (A) and decellularized matrix (B) demonstrating the absence of cellular/nuclear components and the presence of collagenous structure in the decellularized matrix. $C-D$ panels: VVG staining of native tissue (C) and decellularized matrix (D) showing the presence of collagen proteins stained red and elastin proteins stained black in the decellularized matrix. E-F panels: PAS staining of native (E) and decellularized matrix (F) demonstrated the presence of glycoproteins and proteoglycans in the decellularized matrix (arrows). Scale bars $=100 \mu \mathrm{m}$. 
Table 1. Quantitative analysis of decellularization verification and ECM components in native goat-lung tissue (control) and decellularized goat-lung tissue.

\begin{tabular}{|l|l|l|l|l|}
\hline Groups & & $\begin{array}{l}\text { Native tissue } \\
\text { (Control) }\end{array}$ & Decellularized tissue & Remarks \\
\hline $\begin{array}{l}\text { Decellularization } \\
\text { verification }\end{array}$ & DNA quantification & $875.3 \pm 61.42$ & $34.2 \pm 6.5$ & $\begin{array}{l}\text { Significant cell removal } \\
\text { from decellularized matrix }\end{array}$ \\
\hline & DAPI staining & 100 & 0 & Absence of cells in decellularized matrix \\
\hline $\begin{array}{l}\text { Quantitative analysis of ECM } \\
\text { components }\end{array}$ & H\&E staining & 100 & $90.10 \pm 7.71$ & Presence of collagen and absence of cells in decellularized matrix \\
\hline & VVG staining & 100 & $92.23 \pm 9.8$ & Presence of collagen and elastin in decellularized matrix \\
\hline & PAS staining & 100 & $88.29 \pm 2.36$ & Presence of glycoproteins in decellularized matrix \\
\hline
\end{tabular}

DNA quantification is expressed as ng of DNA per mg of tissue sample. DAPI, H\&E, VVG and PAS staining correspond to percentage (\%) in reference to native goat-lung tissue, and are expressed as means \pm standard deviations.

nuclei (Figure 2B). This indicates an effective elimination of cellular components during the decellularization process while maintaining the major ECM components (collagen and elastin) of the lung matrix. The presence of collagen fibers in the ECM of decellularized tissue was also demonstrated by H\&E staining. The collagen fibers gets stained with eosin and appeared pink in color, which indicated the maintenance of collagenous matrix structure in the decellularized tissue (Figure 2D). The result of H\&E staining also confirmed the presence of cells (nuclei stained blue) in the native tissue (Figure 2C) and absence of nuclear counterstaining in the decellularized tissue (Figure 2D). PAS staining helps in the evaluation of glycoproteins and present in the matrix [64]. The positive result of PAS staining (Figure $2 \mathrm{E}$ and $2 \mathrm{~F}$ ) verifies the existence of glycoproteins in the decellularized matrix.

The quantitative assessment of the collagen, elastin and glycoproteins in the decellularized tissue (Table 1) was demonstrated by Image J program. For each stained image, 5 small areas were randomly selected $(n=5)$ and the staining intensity was calculated. VVG stained image and H\&E stained image demonstrated good staining intensity, over $90 \%$ of the control (native tissue), for VVG stain (92.23 \pm 9.8$)$ and $\mathrm{H} \& \mathrm{E}$ stain $(90.10 \pm 7.71)$, which suggested the preservation of collagen and elastin proteins in the decellularized tissue, thus maintaining the $3 \mathrm{D}$ structural integrity of the goat-lung tissue. The assessment of PAS stained images(staining intensity of $88.29 \pm 2.36$ ) suggested the presence of glycoproteins with some loss during decellularization process. It was expected that some of the proteins would get dissolved and washed away during decellularization process as SDS tend to solubilize the ECM proteins $[19,60,65]$. Previous study by Oliveria et al. [58] has also performed similar histologic assessment using Image J program. Taken together, VVG, H\&E and PAS staining confirmed that decellularized goat-lung matrix was devoid of cells and the ECM components (collagen, elastin and glycoproteins) were still retained in the matrix, after decellularization: these will help in maintaining the structural and functional properties of the ECM, which can be used as tissue engineering scaffold.

\section{In vitro biodegradation of decellularized goat-lung matrix}

Biodegradability is one of an important characteristic for tissue engineering scaffold. Following implantation, degradation of scaffold biomaterial is an essential step for constructive remodeling of the tissue [66]. As the major constituent of lung ECM comprises collagen proteins, therefore, collagenase enzyme was chosen to perform the biodegradation of decellularized lung matrix. The in vitro biodegradation of decellularized goat-lung matrix was evaluated by quantifying the weight loss after treating the matrix with $0.2 \%$ collagenase enzyme (Figure 3 ) at $37^{\circ} \mathrm{C}$ in $1 \mathrm{X}$ PBS solution. The results of in vitro biodegradation of decellularized goat-lung matrix showed that with the progression of days, the matrix gradually degrades, and after $60 \mathrm{~h}$, the matrix was completely degraded. This result confirms

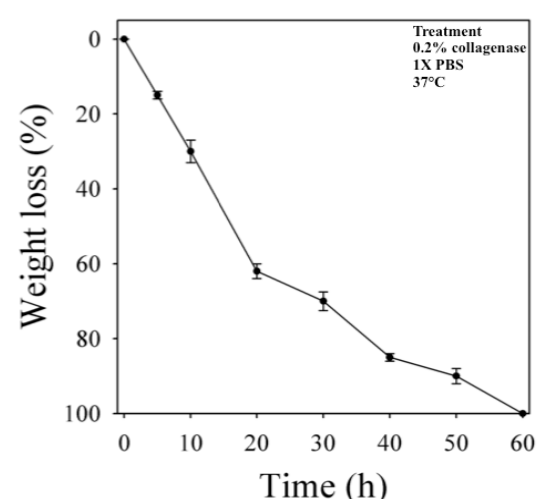

Figure 3. Representative image showing percentage weight loss of decellularized goatlung matrix incubated in $1 \mathrm{X}$ PBS containing $0.2 \%$ collagenase at $37^{\circ} \mathrm{C}$ for $60 \mathrm{~h}$. Data are expressed as means \pm standard deviations.

that collagenases (endopeptidase) helped in degrading the triple helix region of the collagen molecule present in the ECM $[67,68]$.

It has been reported earlier that the in vitro degradation of scaffold differs from in vivo degradation process as various matrix metalloproteinases [69] and macrophages [70,71] are responsible for degrading biological scaffold materials in vivo. The in vitro biodegradation of decellularized lung scaffold by $0.2 \%$ concentration of collagenase was used as an 'accelerated model' of degradation and the collagenase activities in vivo are not expected to be as harsh as in vitro [72]. Moreover, the degradation rates of the scaffold can be controlled by varying the enzyme concentrations [73] or by using various crosslinking agents (carbodiimide, glutaraldehyde), which might affect the collagen structure of the scaffold and modify the cleavage sites for collagenase enzyme [60,74,75]. These results are an in vitro approximation, and the degradation characteristic provide an insight that the decellularized goat-lung matrix is highly biodegradable and could be used as potential biomaterial for tissue regeneration.

\section{Antibacterial activity of decellularized goat-lung matrix}

In vitro collagenase mediated degradation of decellularized goat-lung scaffold have been used as a model for demonstrating the antibacterial effects of degradation products. The results of antibacterial study (Figure 4) showed that the naturally occurring peptides obtained from the degradation of decellularized goat-lung matrix demonstrated activity against both Gram-positive (E. coli) and Gram-negative bacteria ( $S$. aureus). The decellularized goatlung matrix, after collagenase treatment, releases some bioactive peptides molecule, which significantly inhibited the growth of $E$. coli up to $9 \mathrm{~h}$ (Figure 4A), and the growth of $S$. aureus (Figure 4B) up to 5 h. After inhibiting the growth of $E$. coli and $S$. aureus for $9 \mathrm{~h}$ and $5 \mathrm{~h}$ 

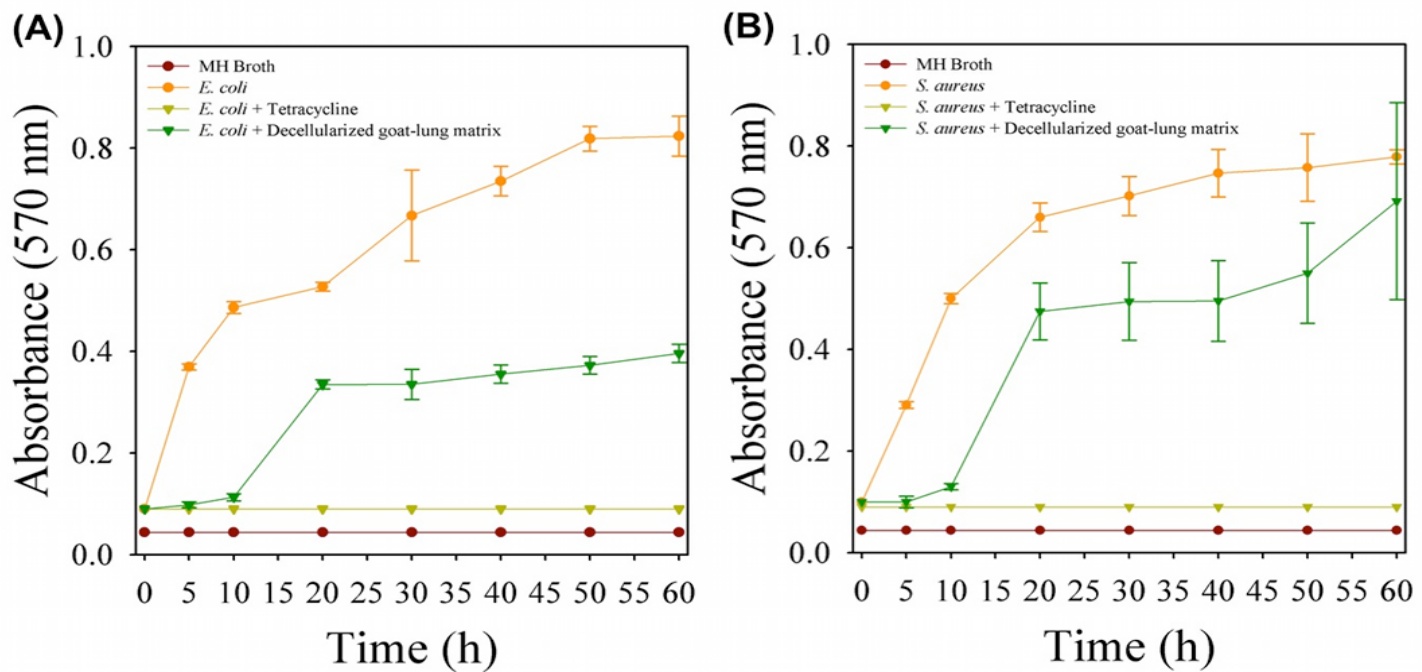

Figure 4. Antibacterial activity of decellularized goat-lung matrix digests on the growth of (A) gram-negative bacteria, E. coli and (B) gram-positive bacteria, S. aureus. Data are shown as means \pm standard deviations with significance at $\mathrm{p}<0.05$.

respectively, the antibacterial activity of goat-lung matrix components gets diminished and bacterial cells started increasing their growth and proliferation. This short term antibacterial effects of degradation products of decellularized goat-lung ECM is supposed to help in providing an immediate protection to the implanted tissue, until humoral immune response and host cell inflammatory response become activated. Similar type of activity has been demonstrated by the ECM scaffold components derived from small intestinal submucosa (SIS) and urinary bladder sub-mucosa (UBS), which exhibit antibacterial activity against both Gram-negative and Gram-positive bacteria [76]. The antibacterial activity against $E$. coli and $S$. aureus has also been examined for porcine liver tissue and superficial layers of the porcine urinary bladder [77]. Although the exact mechanism of killing bacteria by action of peptides (produced during the degradation of the goat-lung ECM) is poorly understood [78], but it has been reported that either the antibacterial peptides may get directly associated with the bacterial cell membrane leading to lysis of the membrane or they get diffused into the bacterial cell cytoplasm and interferes with their protein synthesis [79]. The difference in antibacterial activity (Figure 4) of the peptides against $E$. coli and $S$. aureus might be due to difference in the defense mechanism of the bacteria. The intact decellularized goat-lung ECM (without collagenase digestion) did not possess any antibacterial activity, and similar findings have been reported in a previous study [80]. Thus, the result of antibacterial activity shows that decellularized goat-lung ECM digests have the potential to inhibit the growth of both Gram-positive and Gram-negative bacteria, thereby, proving its potential for tissue engineering applications. Therefore, if the decellularized goat-lung matrix is used as a tissue-engineering scaffold, then it will gradually degrade in vivo and release antibacterial peptides continuously- providing a sustained antibacterial effect in the host.

\section{Biocompatibility and cell viability study by MTT assay}

In order to assess whether xenogeneic decellularized goat-lung matrix would offer safe, non-cytotoxic and biocompatible scaffold for tissue regeneration, MTT assay was performed. We used various different types of cells (L929, HepG2, skin derived mesenchymal stem cells, osteoblasts and bone derived mesenchymal stem cells) to check the biocompatibility, viability and proliferation of all the cells over

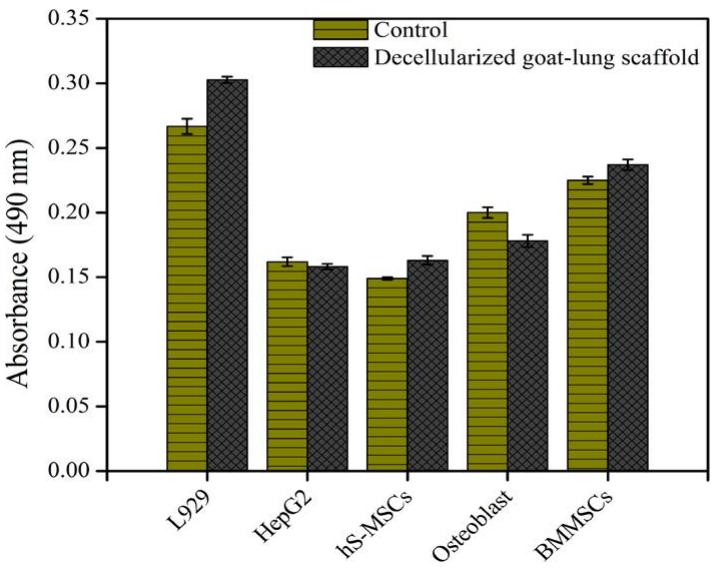

Figure 5. Biocompatibility and viability of L929, HepG2, skin derived mesenchymal stem cells (hS-MSCs), osteoblasts and bone derived mesenchymal stem cells (BMMSCs) over decellularized goat-lung matrix, assessed by MTT assay for $48 \mathrm{~h}$. Absorbance was measured in replicates of three and the calculated standard error of the mean plotted as error bars. Here, absorbance is directly proportional to cell viability.

decellularized goat-lung matrix. The result of MTT assay (Figure 5) showed that the decellularized goat-lung matrix was biocompatible and the cell viability was not affected after $48 \mathrm{~h}$ ( 2 days) of cell culture. All the cells were able to metabolize the MTT substrate, which indicates that the cell's mitochondria were functional over decellularized goatlung matrix, and resulted in good cell viability and proliferation. Thus, MTT assay demonstrated that the decellularized goat-lung matrix, a xenogeneic tissue, constitutes a biocompatible biomaterial for cell culture, and could be used as a potential scaffold for tissue engineering applications.

\section{Conclusion}

Decellularized goat-lung matrix retained the structural 3D architecture after decellularization, and therefore it can be used as 3D scaffold for tissue engineering. The presence of collagen, elastin and glycoproteins in the decellularized goat-lung matrix, as demonstrated by VVG staining, H\&E staining and PAS staining, provided the 
structural support and bio-functional properties for cell growth and proliferation. The in vitro biodegradation of the decellularized matrix reflected the release the bioactive peptides, which exhibit antibacterial activity against $E$. coli and $S$. aureus. The viability of various cells (L929, HepG2, skin derived mesenchymal stem cells, osteoblasts and bone derived mesenchymal stem cells) over the xenogeneic decellularized goat-lung matrix revealed the biocompatibility and non-cytotoxic effects of the decellularized goat-lung matrix on the cellular metabolic activity. Thus, this study demonstrated the feasibility of using the decellularized goat-lung matrix as a potential scaffold for tissue engineering applications.

\section{Acknowledgement}

The authors appreciate the suggestions given by Dr. Amiq Gazdhar, Universität Bern, Bern and acknowledge him. The authors are also thankful to Council of Scientific and Industrial Research (Grant No. 27(0222)/10/EM R-II dated 31.05.10) and Ministry of Human Resource and Development for the financial assistance to carry out this research work.

\section{References}

1. Calve S, Odelberg SJ, Simon HG (2010) A transitional extracellular matrix instructs cell behavior during muscle regeneration. Dev Biol 344: 259-271. [Crossref]

2. Fu RH, Wang YC, Liu SP, Shih TR, Lin HL, et al. (2014) Decellularization and recellularization technologies in tissue engineering. Cell Transplant 23: 621-630. [Crossref]

3. Johnson C, Sheshadri P, Ketchum JM, Narayanan LK, Weinberger PM, et al. (2016) In vitro characterization of design and compressive properties of 3D-biofabricated decellularized hybrid grafts for tracheal tissue engineering. J Mech Behav Biomed Mater 59: 572-585. [Crossref]

4. Patnaik SS, Wang B, Weed B (2014) Decellularized Scaffolds: Concepts, Methodologies, and Applications in Cardiac Tissue Engineering and Whole-Organ Regeneration. Tissue Regeneration: Where Nanostructure Meets Biology 1-48.

5. Rana D, Zreiqat H, Benkirane-Jessel N, Ramakrishna S, Ramalingam M (2015) Development of decellularized scaffolds for stem cell-driven tissue engineering. $J$ Tissue Eng Regen Med. 2-4. [Crossref]

6. Gilbert TW, Stolz DB, Biancaniello F, Simmons-Byrd A, Badylak SF (2005) Production and characterization of ECM powder: implications for tissue engineering applications. Biomaterials 26: 1431-1435. [Crossref]

7. Cozad MJ, Bachman SL, Grant SA (2011) Assessment of decellularized porcine diaphragm conjugated with gold nanomaterials as a tissue scaffold for wound healing. J Biomed Mater Res A 99: 426-434. [Crossref]

8. Mantovani F, Trinchieri A, Castelnuovo C, Romano AL, Pisani E (2003) Reconstructive urethroplasty using porcine acellular matrix. Eur Urol 44: 600-602. [Crossref]

9. Jernigan TW, Croce MA, Cagiannos C, Shell DH, Handorf CR, et al. (2004) Small intestinal submucosa for vascular reconstruction in the presence of gastrointestinal contamination. Ann Surg 239: 733- 738. [Crossref]

10. Kim MS, Hong KD, Shin HW, Kim SH, Lee MS, et al. (2005) Preparation of porcine small intestinal submucosa sponge and their application as a wound dressing in fullthickness skin defect of rat. Int J Biol Macromol 36: 54-60. [Crossref]

11. Shell DH, Croce MA, Cagiannos C, Jernigan TW, Edwards N, et al. (2005) Comparison of small-intestinal submucosa and expanded polytetrafluoroethylene as a vascular conduit in the presence of gram-positive contamination. Ann Surg 241: 995-1001. [Crossref]

12. Rieder E, Kasimir MT, Silberhumer G, Seebacher G, Wolner E, et al. (2004) Decellularization protocols of porcine heart valves differ importantly in efficiency of cell removal and susceptibility of the matrix to recellularization with human vascular cells. J Thorac Cardiovasc Surg 127: 399-405. [Crossref]

13. Schenke-Layland K, Vasilevski O, Opitz F, König K, Riemann I, et al. (2003) Impact of decellularization of xenogeneic tissue on extracellular matrix integrity for tissue engineering of heart valves. J Struct Biol 143: 201-208. [Crossref]

14. Rieder E, Kasimir MT, Silberhumer G, Seebacher G, Wolner E, et al. (2004) Decellularization protocols of porcine heart valves differ importantly in efficiency of cell removal and susceptibility of the matrix to recellularization with human vascular cells. J Thorac Cardiovasc Surg 127: 399-405. [Crossref]

15. Zhai W, Lu X, Chang J, Zhou Y, Zhang H (2010) Quercetin-crosslinked porcine heart valve matrix: mechanical properties, stability, anticalcification and cytocompatibility. Acta Biomater 6: 389-395. [Crossref]

16. Chen RN, Ho HO, Tsai YT, Sheu MT (2004) Process development of an acellular dermal matrix (ADM) for biomedical applications. Biomaterials 25: 2679-2686. [Crossref]

17. Jarman-Smith ML, Bodamyali T, Stevens C, Howell JA, Horrocks M (2004) Porcine collagen crosslinking, degradation and its capability for fibroblast adhesion and proliferation. J Mater Sci Mater Med 15: 925- 932. [Crossref]

18. Lin P, Chan WC, Badylak SF, Bhatia SN (2004) Assessing porcine liver-derived biomatrix for hepatic tissue engineering. Tissue Eng 10: 1046-1053. [Crossref]

19. Woods T, Gratzer PF (2005) Effectiveness of three extraction techniques in the development of a decellularized bone-anterior cruciate ligament-bone graft. Biomaterials 26: 7339-7349. [Crossref]

20. Sullivan DC, Mirmalek-Sani SH, Deegan DB, Baptista PM, Aboushwareb T, et al (2012) Decellularization methods of porcine kidneys for whole organ engineering using a high-throughput system. Biomaterials 33: 7756-7764. [Crossref]

21. Mendoza-Novelo B, Avila EE, Cauich-Rodríguez JV, Jorge-Herrero E, Rojo FJ, et al (2011) Decellularization of pericardial tissue and its impact on tensile viscoelasticity and glycosaminoglycan content. Acta biomaterialia 7: 1241-1248. [Crossref]

22. Schmidt CE, Baier JM (2000) Acellular vascular tissues: natural biomaterials for tissue repair and tissue engineering. Biomaterials 21: 2215-2231. [Crossref]

23. Hudson TW, Liu SY, Schmidt CE (2004) Engineering an improved acellular nerve graft via optimized chemical processing. Tissue Eng 10: 1346-1358. [Crossref]

24. Borschel GH, Dennis RG, Kuzon WM Jr. (2004) Contractile skeletal muscle tissueengineered on an acellular scaffold. Plast Reconstr Surg 113: 595-602. [Crossref]

25. Cartmell JS, Dunn MG (2000) Effect of chemical treatments on tendon cellularity and mechanical properties. J Biomed Mater Res 49: 134-140. [Crossref]

26. Xu CC, Chan RW, Tirunagari N (2007) A biodegradable, acellular xenogeneic scaffold for regeneration of the vocal fold lamina propria. Tissue Eng 13: 551-566. [Crossref]

27. Xu CC, Chan RW, Weinberger DG, Efune G, Pawlowski KS (2010) A bovine acellular scaffold for vocal fold reconstruction in a rat model. $J$ Biomed Mater Res A 92: 18-32. [Crossref]

28. Pandiyan GD, Ghosh PR, Das BC, Das PK, Sanyal S (2005) Studies on sodium and potassium metabolism and subsequent influence on electrocardiogram in unilaterally adrenalectomized black Bengal goat (Capra hircus). J Vet Sci 6: 273-278. [Crossref]

29. Ramasamy I, Law M, Collins S, Brooke F (2003) Organ distribution of prion proteins in variant Creutzfeldt-Jakob disease. Lancet Infect Dis 3: 214-222. [Crossref]

30. Banerjee I, Mishra D, Das T, Maiti S, Maiti TK (2012) Caprine (goat) collagen: a potential biomaterial for skin tissue engineering. J Biomater Sci Polym Ed 23: 355-373. [Crossref]

31. Manuelidis L, Liu Y, Mullins B (2009) Strain-specific viral properties of variant Creutzfeldt-Jakob disease (vCJD) are encoded by the agent and not by host prion protein. J Cell Biochem 106: 220-231. [Crossref]

32. Scott MR, Will R, Ironside J, Nguyen HO, Tremblay P, et al. (1999) Compelling transgenetic evidence for transmission of bovine spongiform encephalopathy prions to humans. Proc Natl Acad Sci U S A 96: 15137-15142. [Crossref]

33. Moulin GCd (2002) Methods of Tissue Engineering. In: Atala A and Lanza RP, (Eds.) California, USA: Academic Press, p.85.

34. Vaccari G, Panagiotidis CH, Acin C, Peletto S, Barillet F, et al. (2009) State-of-the-art review of goat TSE in the European Union, with special emphasis on PRNP genetics and epidemiology. Vet Res 40: 48. [Crossref]

35. Brown P, Cathala F, Raubertas RF, Gajdusek DC, Castaigne P (1987) The epidemiology of Creutzfeldt-Jakob disease: conclusion of a 15-year investigation in France and review of the world literature. Neurology 37: 895-904. [Crossref]

36. Harries-Jones R, Knight R, Will RG, Cousens S, Smith PG, et al. (1988) CreutzfeldtJakob disease in England and Wales, 1980-1984: a case-control study of potential risk factors. J Neurol Neurosurg Psychiatry 51: 1113-1119. [Crossref]

37. Kondo K, Kuroiwa Y (1982) A case control study of Creutzfeldt-Jakob disease association with physical injuries. Ann Neurol 11: 377-381. [Crossref] 
38. Petersen TH, Calle EA, Colehour MB, Niklason LE (2012) Matrix composition and mechanics of decellularized lung scaffolds. Cells Tissues Organs 195: 222-231 [Crossref].

39. Antunes MA, Abreu SC, Damaceno-Rodrigues NR, Parra ER, Capelozzi VL, et al. (2009) Different strains of mice present distinct lung tissue mechanics and extracellular matrix composition in a model of chronic allergic asthma. Respir Physiol Neurobiol 165: 202-207. [Crossref]

40. Davis GE, Bayless KJ, Davis MJ, Meininger GA (2000) Regulation of tissue injury responses by the exposure of matricryptic sites within extracellular matrix molecules. Am J Pathol 156: 1489-1498. [Crossref]

41. Anderson JM (2004) Inflammation, Wound Healing, and the Foreign-Body Response. In: Ratner BD, Hoffman AS, Schoen FJ and Lemons JE, (Eds.). Biomaterials Science: An Introduction to Materials in Medicine. Academic Press, p. 165

42. Kumar V, Abbas AK, Fausto N, Astor J (2005) Acute and Chronic Inflammation. In: Kumar V, Abbas AK and Fausto N, (Eds.). Robbins \& Cotran Pathologic Basis of Disease. Saunders; 8th edition (June 11, 2009), p.47.

43. Ortega N, Werb Z (2002) New functional roles for non-collagenous domains of basement membrane collagens. J Cell Sci 115: 4201-4214. [Crossref]

44. Xu J, Rodriguez D, Petitclerc E, Kim JJ, Hangai M, et al. (2001) Proteolytic exposure of a cryptic site within collagen type IV is required for angiogenesis and tumor growth in vivo. J Cell Biol 154: 1069-1079. [Crossref]

45. Xu R, Yao ZY, Xin L, Zhang Q, Li TP, et al. (2001) NC1 domain of human type VIII collagen (alpha 1) inhibits bovine aortic endothelial cell proliferation and causes cell apoptosis. Biochem Biophys Res Commun 289: 264-268. [Crossref]

46. Ramchandran R, Dhanabal M, Volk R, Waterman MJ, Segal M, et al. (1999) Antiangiogenic activity of restin, $\mathrm{NC10}$ domain of human collagen $\mathrm{XV}$ : comparison to endostatin. Biochem Biophys Res Commun 255: 735-739. [Crossref]

47. Senior RM, Griffin GL, Mecham RP (1980) Chemotactic activity of elastin-derived peptides. J Clin Invest 66: 859-862. [Crossref]

48. Senior RM, Griffin GL, Mecham RP (1982) Chemotactic responses of fibroblasts to tropoelastin and elastin-derived peptides. J Clin Invest 70: 614-618. [Crossref]

49. Ambesi A, Klein RM, Pumiglia KM, McKeown-Longo PJ (2005) Anastellin, a fragment of the first type III repeat of fibronectin, inhibits extracellular signal-regulated kinase and causes $\mathrm{G}(1)$ arrest in human microvessel endothelial cells. Cancer Res 65: 148-156. [Crossref]

50. Ponce ML, Hibino S, Lebioda AM, Mochizuki M, Nomizu M, et al. (2003) Identification of a potent peptide antagonist to an active laminin-1 sequence that blocks angiogenesis and tumor growth. Cancer Res 63: 5060-5064. [Crossref]

51. Schenk S, Quaranta V (2003) Tales from the crypt[ic] sites of the extracellular matrix. Trends Cell Biol 13: 366-375. [Crossref]

52. Mongiat M, Sweeney SM, San Antonio JD, Fu J, Iozzo RV (2003) Endorepellin, a novel inhibitor of angiogenesis derived from the $\mathrm{C}$ terminus of perlecan. $J$ Biol Chem 278: 4238-4249. [Crossref]

53. Slevin M, Kumar S, Gaffney J (2002) Angiogenic oligosaccharides of hyaluronan induce multiple signaling pathways affecting vascular endothelial cell mitogenic and wound healing responses. J Biol Chem 277: 41046-41059. [Crossref]

54. Chen WY, Abatangelo G (1999) Functions of hyaluronan in wound repair. Wound Repair Regen 7: 79-89. [Crossref]

55. Deed R, Rooney P, Kumar P, Norton JD, Smith J, et al. (1997) Early-response gene signalling is induced by angiogenic oligosaccharides of hyaluronan in endothelial cells. Inhibition by non-angiogenic, high-molecular-weight hyaluronan. Int $J$ Cancer 71 : 251-256. [Crossref]

56. Senger DR, Perruzzi CA (1996) Cell migration promoted by a potent GRGDScontaining thrombin-cleavage fragment of osteopontin. Biochim Biophys Acta 1314(12):13-24 [Crossref]

57. Gutierrez ML, Guevara J, Barrera LA (2012) Semi-automatic grading system in histologic and immunohistochemistry analysis to evaluate in vitro chondrogenesis. Universitas Scientiarum 17: 167

58. Oliveira AC, Garzón I, Ionescu AM, Carriel V, Cardona Jde L, et al. (2013) Evaluation of small intestine grafts decellularization methods for corneal tissue engineering. PloS one 8: e66538. [Crossref]

59. Tiete AR, Sachweh JS, Roemer U, Kozlik-Feldmann R, Reichart B, et al. (2004) Right ventricular outflow tract reconstruction with the Contegra bovine jugular vein conduit: A word of caution. Ann Thorac Surg 77: 2151-2156. [Crossref]
60. Crapo PM, Gilbert TW, Badylak SF (2011) An overview of tissue and whole organ decellularization processes. Biomaterials 32: 3233-3243. [Crossref]

61. Bolland F, Korossis S, Wilshaw SP, Ingham E, Fisher J, et al. (2007) Development and characterisation of a full-thickness acellular porcine bladder matrix for tissue engineering. Biomaterials 28: 1061-1070. [Crossref]

62. Carvalho JL, Carvalho PH, Gomes DA, Goes AM (2012) Characterization of Decellularized Heart Matrices as Biomaterials for Regular and Whole Organ Tissue Engineering and Initial In-vitro Recellularization with Ips Cells. J Tissue Sci Eng Suppl 11: 002. [Crossref]

63. Shafiq MA, Gemeinhart RA, Yue BY, Djalilian AR (2012) Decellularized human cornea for reconstructing the corneal epithelium and anterior stroma. Tissue Eng Part C Methods 18: 340-348. [Crossref]

64. Naderi S, Khayat Zadeh J, Mahdavi Shahri N, Nejad Shahrokh Abady K, Cheravi M, et al. (2013) Three-dimensional scaffold from decellularized human gingiva for cell cultures: glycoconjugates and cell behavior. Cell J 15: 166-175. [Crossref]

65. Cartmell JS, Dunn MG (2000) Effect of chemical treatments on tendon cellularity and mechanical properties. J Biomed Mater Res 49: 134-140. [Crossref]

66. Wolf MT, Daly KA, Brennan-Pierce EP, Johnson SA, Carruthers CA, et al. (2012) A hydrogel derived from decellularized dermal extracellular matrix. Biomaterials 33 7028-7038. [Crossref]

67. Gorgieva S, Kokol V (2011) Collagen- vs. Gelatine-Based Biomaterials and Their Biocompatibility: Review and Perspectives. In: Pignatello R, (Ed.). Biomaterials Applications for Nanomedicine p.1.

68. Mendoza-Novelo B, Cauich-Rodri' guez JV (2011) Decellularization, Stabilization and Functionalization of Collagenous Tissues Used as Cardiovascular Biomaterials. In: Pignatello R, (Ed.). Biomaterials - Physics and Chemistry InTech, p.159.

69. Lu P, Takai K, Weaver VM, Werb Z (2011) Extracellular matrix degradation and remodeling in development and disease. Cold Spring Harb Perspect Biol 3. [Crossref]

70. Valentin JE, Turner NJ, Gilbert TW, Badylak SF (2010) Functional skeletal muscle formation with a biologic scaffold. Biomaterials 31: 7475-7484. [Crossref]

71. Valentin JE, Stewart-Akers AM, Gilbert TW, Badylak SF (2009) Macrophage participation in the degradation and remodeling of extracellular matrix scaffolds. Tissue Eng Part A 15: 1687-1694. [Crossref]

72. Tedder ME, Liao J, Weed B, Stabler C, Zhang H, et al. (2009) Stabilized collagen scaffolds for heart valve tissue engineering. Tissue Eng Part A 15: 1257-1268. [Crossref]

73. Kim BS, Choi JS, Kim JD, Choi YC, Cho YW (2012) Recellularization of decellularized human adipose-tissue-derived extracellular matrix sheets with other human cell types. Cell Tissue Res 348: 559-567. [Crossref]

74. Song JJ, Ott HC (2011) Organ engineering based on decellularized matrix scaffolds Trends Mol Med 17: 424-432. [Crossref]

75. Liang HC, Chang Y, Hsu CK, Lee MH, Sung HW (2004) Effects of crosslinking degree of an acellular biological tissue on its tissue regeneration pattern. Biomaterials. 25 3541-3552. [Crossref]

76. Sarikaya A, Record R, Wu CC, Tullius B, Badylak S, et al. (2002) Antimicrobial activity associated with extracellular matrices. Tissue Eng 8: 63-71. [Crossref]

77. Brennan EP, Reing J, Chew D, Myers-Irvin JM, Young EJ, et al. (2006) Antibacteria activity within degradation products of biological scaffolds composed of extracellular matrix. Tissue Eng 12: 2949-5295. [Crossref]

78. Boman HG (1995) Peptide antibiotics and their role in innate immunity. Annu Rev Immunol 13: 61-92. [Crossref]

79. Boman HG, Agerberth B, Boman A (1993) Mechanisms of action on Escherichia col of cecropin P1 and PR-39, two antibacterial peptides from pig intestine. Infect Immun 61: 2978-2984. [Crossref]

80. Holtom PD, Shinar Z, Benna J, Patzakis MJ (2004) Porcine small intestine submucos does not show antimicrobial properties. Clin Orthop Relat Res. 427: 18-21. [Crossref]

Copyright: (C2017 Gupta SK. This is an open-access article distributed under the terms of the Creative Commons Attribution License, which permits unrestricted use, distribution, and reproduction in any medium, provided the original author and source are credited. 